the interactions of other seabird predators, such as large gulls. Young's book raises as many questions as it answers, and it will be of interest to seabird biologists from all climatic zones as well as to biologists specialising in the Antarctic. (R.W. Furness, Applied Ornithology Unit, Zoology Department, University of Glasgow, Glasgow G12 8QQ.)

\section{ARCTIC EXPLORATION AND DEVELOPMENT} C. 500 B.C. TO 1915: AN ENCYCLOPEDIA. Clive Holland. 1994. New York and London: Garland Publishing. xvi + 704 pp, maps, hard cover. ISBN 0-8240-7648-6. US\$125.00.

In 1653 the Danish Northern Company sent out an expedition to explore the Arctic waters north and east of Norway. The expedition apparently reached the Kola Peninsula, the Pechora region, Novaya Zemlya, and Spitsbergen. The only first-hand account written about the voyage was by the Frenchman Pierre Martin Bruzen de la Martinière, the surgeon on one of the three ships. His book was enormously popular, and was issued in at least six languages and 16 editions. However, it owed as much to his vivid imagination as to any semblance of reality, as he not only included a remarkably inaccurate map, but fantastic descriptions of strange fauna and native peoples never seen before or since.

More than two centuries later, the Confederate Navy ship Shenandoah, under the command of James Waddell, sailed through the Pacific and the Sea of Okhotsk to the Bering Sea, where Waddell and his men encountered the US whaling fleet. Within a week, they had captured and burned at least 19 whalers, despite having been told by several captains that the American Civil War had ended more than two months previously (9 April 1865). Working his way back south after being stopped by ice in the Arctic Ocean, Waddell finally received confirmation from a British ship that the Confederate States of America had indeed collapsed and hostilities had ceased. In order to avoid the US Navy, Waddell thereupon sailed around Cape Horn and on to England, having destroyed a total of 29 US whalers.

In 1901 the Russian icebreaker Yermak, having been restrengthened in Newcastle-upon-Tyne, headed toward Novaya Zemlya on a test-run. Stopped by heavy ice, however, Stepan Makarov, the expedition commander, turned to Zemlya Frantsa-Iosifa, and anchored at Mys Flora, his command thereby becoming the first Russian party to reach that archipelago. After conducting some oceanographic work, the expedition again headed for Novaya Zemlya, but was again halted by the ice. These failures to reach Novaya Zemlya were viewed very unfavorably by the Russian government, which removed Makarov from the icebreaker experiments and shelved plans for icebreakers for almost two decades.

These three adventures are only examples of the approximately 1900 expeditions that can be found in Arctic exploration and development, Clive Holland's new sourcebook for the history and exploration of the north.
With this work, Holland, who was the principal architect of the masterful chronology The exploration of northern Canada (Cooke and Holland 1978), has made another major scholarly contribution to northern history. Like its predecessor, this book is a comprehensive chronological record of northern expeditions, voyages, and historical events; however, the current work covers the entire Arctic. In so doing, it details a vast amount of information about which little has been known. Most notable in this vein are the accounts of expeditions in the Russian Arctic, many of which have previously been totally unfamiliar to western researchers. Of course, the book has lengthy summaries of all of the major expeditions and events as well, so that the general reader can benefit from it as much as the specialist. Hudson, Ross, Nordenskiøld, Nansen, Peary, and Stefansson are here, along with the less well-known, but equally significant, Otto Torell, Elling Carlsen, Joseph Wiggins, A.G. Nathorst, and Vladimir Rusanov. Also included are synopses of whaling, hunting, and trading expeditions, including annual accounts of whaling activity since 1624.

Arctic exploration and development is an extremely useful tool for the northern researcher. The entries are, first, chronological and, then, by geographical locations. Each entry has at least one reference, and the book has an extensive bibliography. There is an appendix of significant members of expeditions, with a complete listing of the expeditions upon which they served. The book also includes a geographical glossary, as well as approximately 30 maps. And there are two indexes, one of place-names, companies, and other entries, and one of ships that sailed into the Arctic.

Regrettably, the book does have several editorial flaws. After the proof stage, for example, a number of changes were made that resulted in a lack of consistency in the usage of fjord/fiord, which appears in a variety of forms, some correct, others not. In addition, the maps are in a random order, and one is a draft, rather than a final, copy. Fortunately, these rather minor problems are being corrected for the second printing.

Holland spent many years researching and compiling this work. It is surely destined to repay his efforts by being recognized as a classic in its field, and scholars surely will anxiously await its sequel. (Beau Riffenburgh, Scott Polar Research Institute, University of Cambridge, Lensfield Road, Cambridge CB2 1ER.)

\section{Reference}

Cooke, A., and C. Holland. 1978. The exploration of northern Canada, 500-1920: a chronology. Toronto: Arctic History Press.

THE ARCTIC: A HISTORY. Richard Vaughan. 1994. Stroud, Gloucestershire: Alan Sutton. ix $+340 \mathrm{pp}$, illustrated, hard cover. ISBN 0-7509-0177-2. £20.00.

To attempt to discuss the history of the entire circumpolar Arctic from a mammoth hunt on the Berelekh River in the Indigirka basin around $12,000 \mathrm{BP}$ to the negotiation of the Nunavut settlement in 1993 within the constraints of 340 
pages of text represents a challenge that few scholars would have the temerity to tackle. Richard Vaughan is one of those few, and the result of his efforts is a masterpiece of selection, organization, and synthesis. What is immediately evident is that such a challenge could have been successfully met only by a scholar with Vaughan's impressive command of languages: Dutch, Norwegian, German, and Russian sources are incorporated into the fabric of the book with consummate skill.

One is immediately struck by the fact that the scope of the book is much wider than that of a traditional history of 'exploration' and 'discovery' by incursive Europeans. Many of the traditional ingredients - such as the Royal Navy's search for the Northwest Passage (and, after 1847, for the missing Franklin expedition), the Russian expansion across Siberia and to its Arctic coast, and, a century later, the Russian Navy's remarkably successful Great Northern Expedition - are covered succinctly yet convincingly. But Vaughan also includes important aspects of economic and social history. Thus, one of his most useful contributions is his excellent coverage of Arctic whaling in the late sixteenth and early seventeenth centuries, particularly by the Dutch around Svalbard, where Smeerenburg has long been thought to have been a seventeenth-century whaling metropolis. As Vaughan reports, however, recent Dutch excavations have 'cut Smeerenburg down to size,' revealing it to have been 'more like a typical Dutch singlestreet village' (page 86) and only a seasonal settlement. From these beginings, Vaughan follows the history of Arctic whaling in the North Atlantic, Baffin Bay, Hudson Bay, and the Beaufort and Chukchi seas to its last gasp in Hudson Bay around 1915.

Other chapters focus on the impact of the Hudson's Bay Company and, from a much earlier date, that of the Royal Greenland Trade on the inhabitants of what are now the Canadian Arctic and Greenland. Elsewhere the significant contribution of shipping to the development of the Russian and Siberian Arctic is recognized through a thorough discussion of the development of the Northern Sea Route, under both tsarist and Soviet regimes. Yet another refreshingly different aspect of the content is the chapter on the search for minerals, from the Klondike to Prudhoe Bay and the Yamal Peninsula, and its impacts, positive and negative, on the peoples of the Arctic and the environment.

A particularly refreshing feature of the book is the emphasis on the place of indigenous peoples in the history of the Arctic. It opens with a review of the indigenous peoples around the Arctic at the time of first contact with Europeans (that time varying in each case), and ends with the settlement of the Nunavut land claim and with the optimistic note that this and other recent developments whereby the indigenous peoples have been making progress towards claiming 'what is rightfully their own' will 'remove definitively the threat of their extinction' (page 289).

When the canvas has been painted with such a broad brush, it is inevitable that minor errors have crept in, but these are surprisingly few in number and do not affect the general thrust of the arguments. One might fault Vaughan, for example, for the remark that the three members of Andrée's disastrous expedition in the balloon Örnen 'were entirely without experience of travel and survival in the Arctic' (page 194), whereas Andree had in fact been a member of the Swedish expedition to Kapp Thordsen, Spitsbergen, as part of the International Polar Year in 1882-1883; one might, however, argue, in support of Vaughan's statement, that such an Arctic experience did not necessarily contribute to his skills at either survival or travel. Elsewhere Vaughan suggests that Roald Amundsen's passion for aviation dated only to the period of the Maud expedition (1918-1921), whereas in fact he had obtained his pilot's license in 1914 in preparation for using aircraft on a planned drift across the North Pole in Fram, on the same day as Wilhelm Filchner, the German Antarctic explorer who was also to participate in the expedition. Undoubtedly some readers will fault Vaughan for casting his vote in favour of Peary in the long-running debate as to whether he reached the North Pole or not. In this connection this reviewer would only fault Vaughan for devoting so much valuable space on an activity and a debate that are so peripheral to the real theme of his book, namely the history of the peoples of the Arctic.

Vaughan's book will be invaluable in the classroom and for the general reader, as a sound, comprehensive, and succinct source on the history of the Arctic. To more specialized readers, its value lies in its magnificent, up-todate bibliography, containing more than 850 citations. (William Barr, Department of Geography, University of Saskatchewan, Saskatoon, Saskatchewan S7N 0W0, Canada.)

CLIMATE SINCE A.D. 1500. R.S. Bradley and P.D. Jones (Editors). 1992. London and New York: Routledge. $x v+679 p$, illustrated, hard cover. ISBN 0-415-07593-9. $£ 85.00$.

A basic premise of this book is that the Earth's climate system responds to continuing 'natural' forcing factors, as well as to recent anthropogenic effects. Further, the climate has exhibited significant variability during the past few hundred years, a time period through which human interference was small, relative to the last century. In order to understand the possible effects of recent human activity on future climate, as much as possible needs to be known about natural variability and its causes, because this forms the underlying climate on which anthropogenic effects are superimposed.

The volume is restricted to climatic variations during the last 500 years, a period that, the editors point out, encompasses the bulk of the 'Little Ice Age' and its termination, together with a period of unusual sunspot activity in the Maunder minimum (1645-1715). It is also the period of Earth's history for which the most comprehensive climate records, in both the temporal and spatial domain, can be constructed. Climatic evidence was selected by the editors on the basis that the source had a temporal resolution of one year or better. This not incon- 